\title{
Erratum to: Sustainable energy: a review of formic acid electrochemical fuel cells
}

\author{
Neil V. Rees • Richard G. Compton
}

Published online: 8 December 2011

(C) Springer-Verlag 2011

Erratum to: J. Solid State Electrochem. (2011) 15: 2095-2100 DOI: 10.1007/s10008-011-1398-4

The authors regret an error made in this review (p. 2096).

The main proponents of the bridge-bonded formate pathway being dominant are the Osawa group (see Angew. Chem. Int. Ed. 2011, 50, 1159 and references therein), whereas the Behm group (references as per the review) propose the dominant pathway is via adsorbed formic acid with the formate pathway contributing $<25 \%$ of total current.

The online version of the original article can be found at http://dx.doi. org/10.1007/s10008-011-1398-4.

\footnotetext{
N. V. Rees $\cdot$ R. G. Compton $(\bowtie)$

Physical \& Theoretical Chemistry Laboratory,

Department of Chemistry, Oxford University,

South Parks Road,

Oxford OX1 3QZ, UK

e-mail: richard.compton@chem.ox.ac.uk
} 